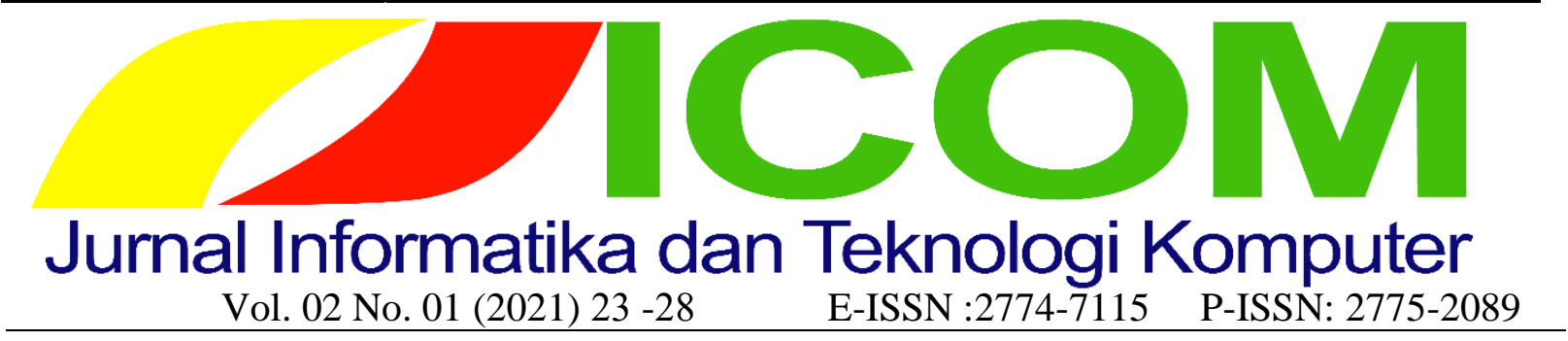

\title{
Sistem Notifikasi Surat Pada Kantor Pemerintahan Kota Langsa Berbasis Web
}

\author{
Harys Fajri ${ }^{1}$, Eka Julianti' ${ }^{2}$, Ahmad Ihsan ${ }^{3}$ \\ ${ }^{1}$ Teknik Informatika, Teknik, Universitas Samudra \\ ${ }^{2}$ Teknik Informatika, Teknik, Universitas Samudra \\ ${ }^{2}$ Teknik Informatika, Teknik, Universitas Samudra \\ 1harys.f27@gmail.com@gmail.com, ${ }^{2}$ ekajulianti07@gmail.com, ${ }^{3}$ ahmadihsan@unsam.ac.id.
}

\begin{abstract}
Notifications are notifications about actions that affect them. This notification can help users be more aware of events related to them and, if they want, can take action quickly, this notification is indispensable for letters, Letters can be interpreted as a means of communication to convey written information by one party to another by purpose tells the intent of the message from the sender. This notification system is made using PHP which will be designed using ERD and DFD and will produce a web with notification system for incoming and outgoing mail.
\end{abstract}

Key words: Notification System, Incoming Mail, Outgoing Mail

Abstrak

Notifikasi adalah pemberitahuan mengenai tindakan yang memengaruhi mereka. Pemberitahuan ini dapat membantu pengguna lebih menyadari peristiwa-peristiwa yang berhubungan dengan mereka dan, jika mereka mau, dapat mengambil tindakan dengan cepat, notifikasi ini sangat diperlukan untuk surat, Surat dapat diartikan menjadi sarana komunikasi untuk menyampaikan informasi tertulis oleh suatu pihak kepada pihak lain dengan tujuan memberitahukan maksud pesan dari si pengirim. Sistem Notifikasi ini dibuat menggunakan PHP yang akan dirancang menggunakan ERD dan DFD dan akan menghasilkan sebuah web dengan sistem notifikasi untuk surat masuk dan surat keluar.

Kata-kata kunci: Sistem Notifikasi, Surat Masuk, Surat Keluar

\section{Pendahuluan}

Pada masa kini teknologi sangat berperan penting di dalam kehidupan bahkan di setiap bidang, teknologi informasi mampu mempermudah aktifitas manusia dalam mengerjakan sesuatu dalam kegitannya seharihari. Di dalam sebuah kantor atau perkantoran itu sangatlah di butuhkan teknologi, salah satu teknologi yang butuhkan salah satunya sistem informasi seperti pendataan surat masuk dan surat keluar, data-data pegawai,dan masih banyak lagi. Di mana di dalam sebuah perusahan masih menggunakan metode-metode manual dalam sebuah perkantoran.

\section{Metode}

\subsection{Definisi Notifikasi}

Notifikasi adalah pemberitahuan mengenai tindakan yang memengaruhi mereka. Pemberitahuan ini dapat membantu pengguna lebih menyadari peristiwaperistiwa yang berhubungan dengan mereka dan, jika mereka mau, dapat mengambil tindakan dengan cepat.

\subsection{Pengertian Surat}

Surat dapat diartikan menjadi sarana komunikasi untuk menyampaikan informasi tertulis oleh suatu pihak kepada pihak lain dengan tujuan memberitahukan maksud pesan dari si pengirim.

\subsection{Konsep Database(Basis Data)}

James Martin mendefinisikan database sebagai suatu kumpulan data yang saling berhubungan dan disimpan 
bersama-sama dengan melakukan pengontrolan terhadap kelengkapan data, untuk melayani satu atau lebih aplikasi secara optimal. Dalam database terdiri dari entity, atribut, data value, record dan file.

\subsection{Perancangan Database}

Merancang database merupakan suatu hal yang sangat penting. Kesulitan utama dalam merancang database adalah bagaimana merancang sehingga database dapat memuaskan keperluan saat ini dan masa mendatang. Perancangan model konseptual perlu dilakukan di samping perancangan model phisik. Pada perancangan model konseptual akan menunjukkan entity dan relasi berdasarkan proses yang diinginkan oleh organisasi. Ketika menentukan entity dan relasi dibutuhkan analisis data tentang informasi yang ada dalam spesifikasi di masa mendatang.

\subsection{ERD (Entity Relationship Diagram)}

ERD (Entity Relationship Diagram) adalah suatu model untuk menjelaskan hubungan antar data dalam basis data berdasarkan objek-objek dasar data yang mempunyai hubungan antar relasi.

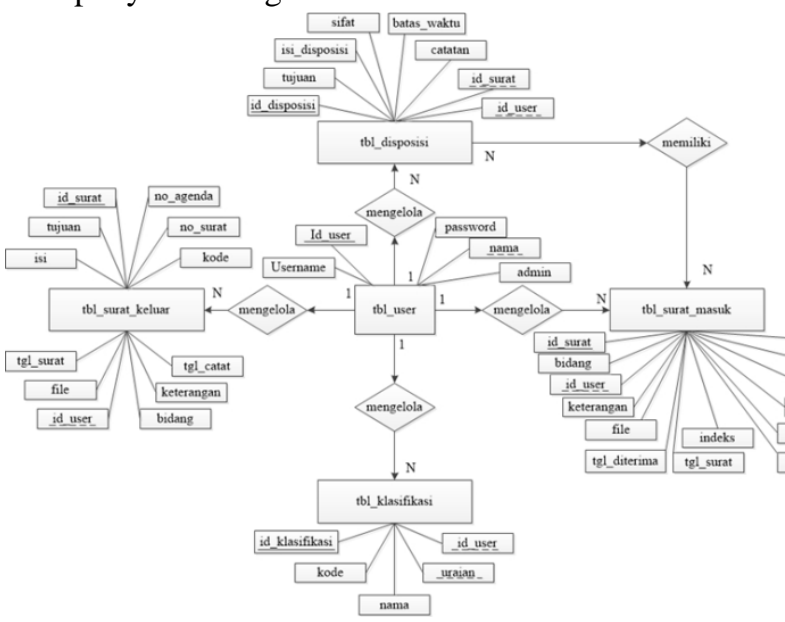

Gambar 1 : ERD

Pada gambar ERD di atas terdapat 4 entitas (manual book) yaitu tbl_surat_keluar, tbl_surat_masuk, tbl_disposisi, dan tbl_klasifikasi. Setiap manual book memiliki atribut untuk melengkapi manual book, atribut pada tbl_surat_keluar adalah id_surat, no_agenda, tujuan, no_surat, isi, kode, tgl_surat, tgl_catat, file, keterangan, id_user, bidang. Sehingga pada surat keluar dapat memberikan informasi seluruh tentang surat yang akan dikeluarkan oleh/dari Kantor Pemerintahan Kota Langsa, mulai dari no_agenda surat hingga dapat melakukan upload file surat yang dapat diunggah dengan ekstensi file berupa *.JPG, *.PNG, *.DOC, *.DOCX, *.PDF dengan ukuran maksimal file $2 \mathrm{MB}$.

\subsection{DFD (Data Flow Diagram)}

Data Flow Diagram (DFD) merupakan suatu cara atau metode untuk membuat rancangan sebuah sistem yang mana berorientasi pada alur data yang bergerak pada sebuah sistem nantinya. Dalam pembuatan Sistem Informasi, DFD sering digunakan. DFD dibuat oleh para analis untuk membuat sebuah sistem yang baik. Dimana DFD ini nantinya diberikan kepada para programmer untuk melakukan proses coding.

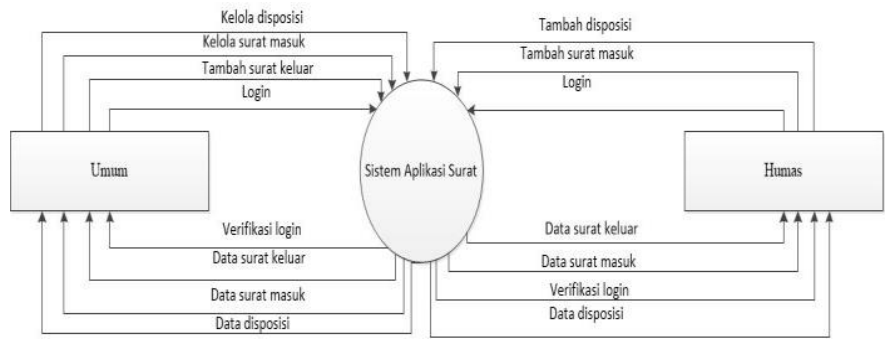

Gambar 2 Diagram konteks Level 1 Umum

Pada diagram konteks di atas menjelaskan bahwa bagian umum dapat melakukan login yang berikutnya akan di verifikasi sebagai umum dan bagian umum dapat mengelola seluruh aktifitas pembuatan disposisi, kelola surat masuk, menambahkan surat keluar, dengan adanya perintah yang diberikan bagian umum kedalam sistem maka sistem akan merespon dengan mengirim data-data yang diminta oleh bagian umum. Pada bagian humas hanya dapat login yang berikutnya akan diverifikasi sebagai humas dan melakukan tambah disposisi, tambah surat serta dengan adanya perintah yang diberikan kedalam sistem maka sistem akan mengirimkan data-data sesuai dengan yang diinginkan oleh bagian humas.

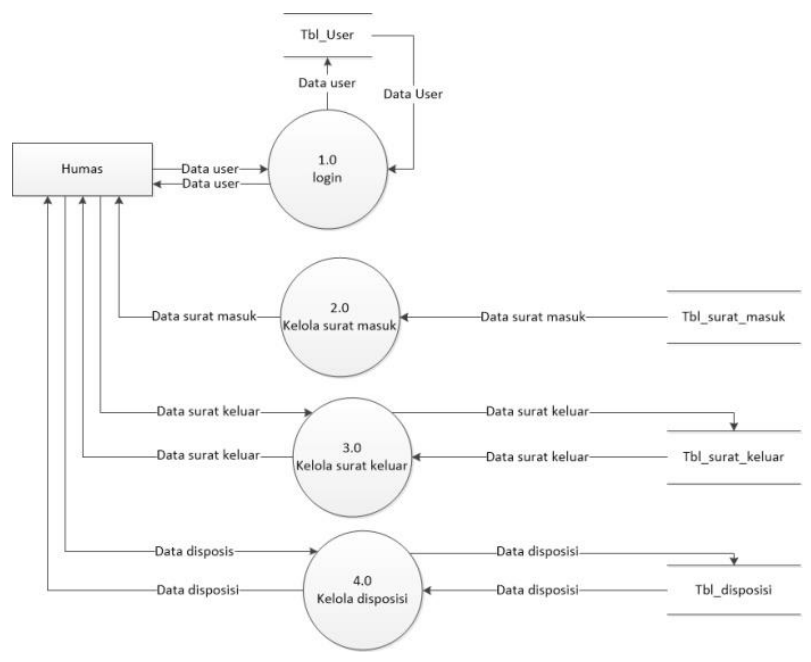

Gambar 3 DFD level 1 (satu) humas

Dalam data flow diagram diatas menjelaskan bahwa bagian humas dapat melakukan login yang berikutnya akan diverifikasi oleh sistem melalui tbl_user yang

Diterima Redaksi : 15-03-2021 | Selesai Revisi : 20-03-2021 | Diterbitkan Online : 01-04-2021 
terdaftar sebagai humas. Setelah login maka humas dapat menerima data surat masuk yang sebelumnya telah diinput oleh bagian umum. Bagian humas berikutnya dapat melakukan pengelolaan terhadap surat keluar pada tabel surat keluar dan pengelolaan disposisi melalui tabel disposisi.

\subsection{MySQL}

MySQL adalah sebuah implementasi dari sistem manajemen basis data relasional yang didistribusikan secara gratis di bawah lisensi GPL (General Public License).

\subsection{PHP}

PHP adalah singkatan dari PHP : Hypertext Preprocessor. Di mana huruf ' $\mathrm{P}$ ' pada kata PHP merupakan singkatan dari kata PHP itu sendiri atau yang sering disebut rekursif.Maksud dari rekursif adalah PHP memiliki kemampuan / fungsi untuk memanggil dirinya sendiri.

Pengertian PHP adalah bahasa pemrograman script server side yang sengaja dirancang lebih cenderung untuk membuat dan mengembangkan web.

\section{Hasil dan Pembahasan}

3.1 Desain Prototype Sistem Notifikasi Surat Desain prototype berisi seluruh bagian yang ada di sistem notifikasi surat, baik dari tampilan login, tapilan login meliputi login umum, dan humas.

\subsection{Tampilan Login}

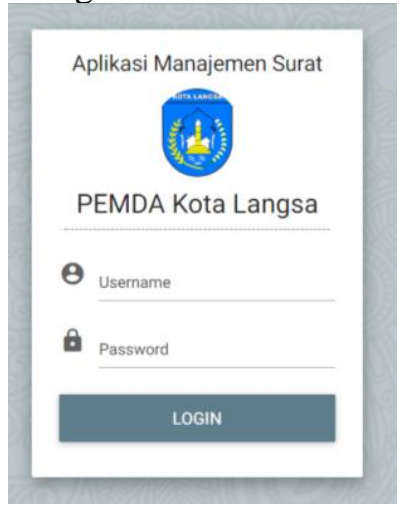

Gambar 4 Tampilan login

Pada tampilan gambar di atas menunjukan tampilan login pada sistem notifikasi surat. Dalam tampilan ini user harus masuk ke dalam aplikasi dengan menggunakan username dan password. Dengan menggunakan nama bagian tempat kantor dalam Pemerintahan Walikota Langsa.

\subsection{Tampilan Beranda Bagian Umum}

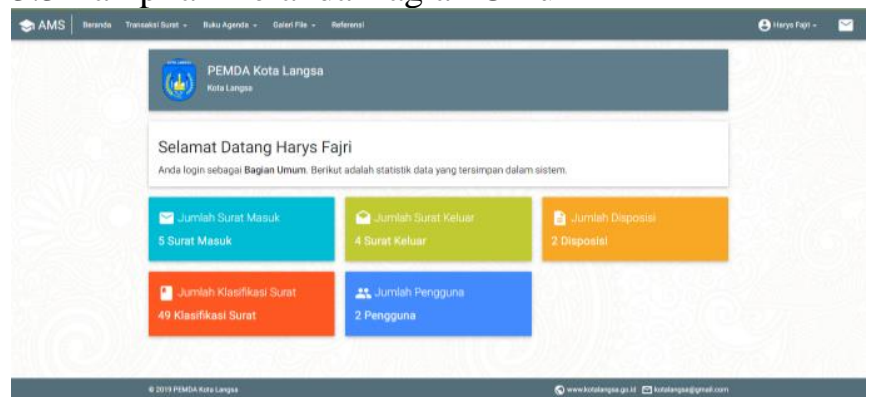

Gambar 5 Tampilan Beranda Bagian Umum

Pada tampilan gambar prototype diatas menjelaskan setelah bagian umum berhasil login atau masuk ke sebuah sistem notifikasi surat maka akan menampilkan tampilan beranda seperti pada gambar di atas. Dimana pada beranda menampilkan pemberitahuan jumlah keseluruhan surat masuk, jumlah surat keluar, jumlah disposisi, jumlah klasifikasi surat dan jumlah pengguna yang terdapat dalam sistem aplikasi notifikasi surat ini.

\subsection{Tampilan Beranda Bagian Humas}

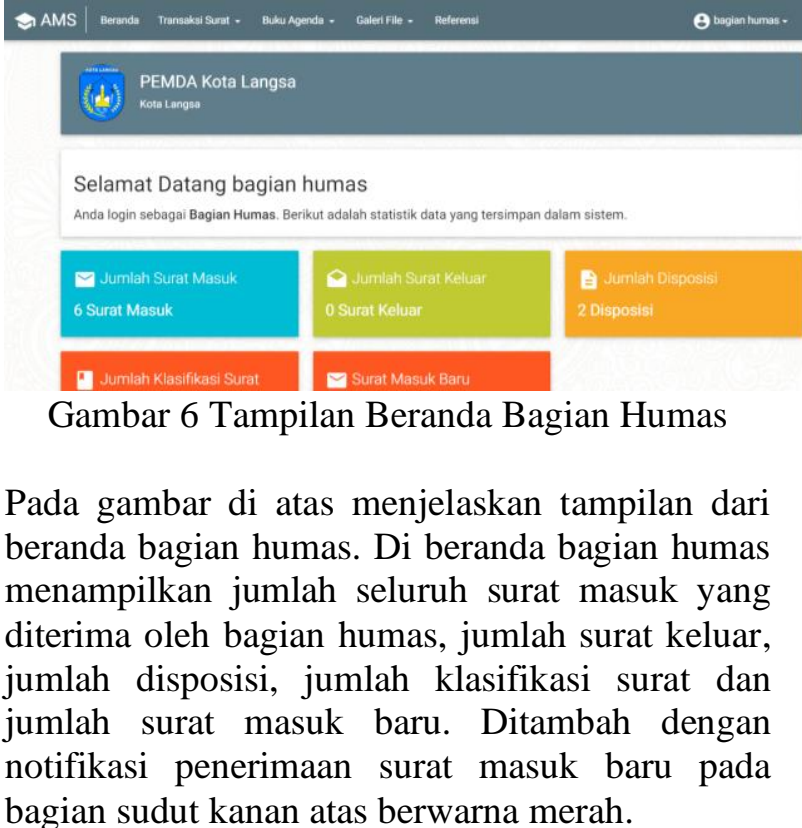

\subsection{Tampilan Data Surat Masuk Bagian Umum}




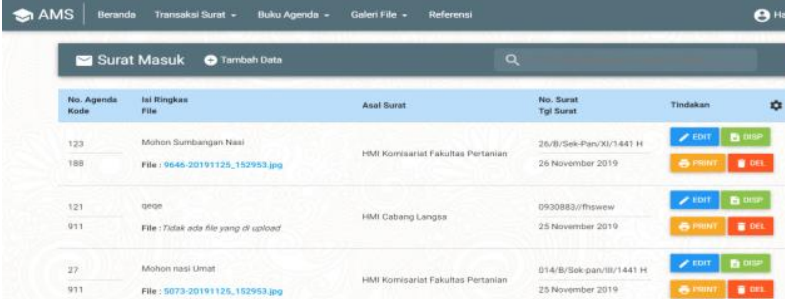

Gambar 7 Tampilan Data Surat Masuk Bagian Umum

Pada gambar diatas menjelaskan bahwa gambar diatas merupakan tampilan pada surat masuk bagian umum. Pada bagian Tambah data berfunsi untuk melakukan penambahan data surat kotak masuk. Pada gambar diatas bagian umum dapat melakukan pengeditan pada surat, membuat disposisi, melakukan print pada disposisi dan melakukan penghapusan data surat masuk

\subsection{Tampilan Notifikasi Surat Masuk}

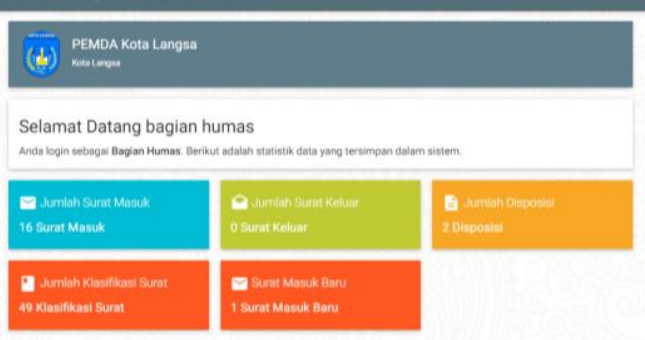

Gambar 8 Tampilan Notifikasi Surat Masuk

Pada Gambar 8 memperlihatkan bahwa pada bagian nama user terdapat notifikasi pemberitahuan bahwa terdapat surat masuk yang belum di baca sesuai dengan jumlah yang diterima oleh bagian humas.

\subsection{Tampilan Data Surat Masuk Bagian Humas}

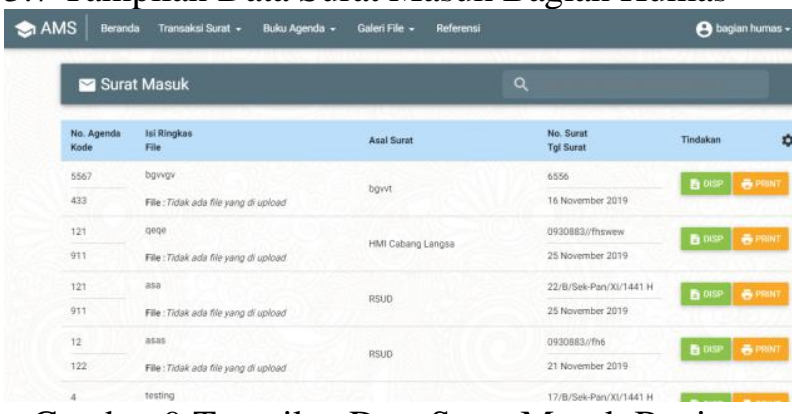

Gambar 9 Tampilan Data Surat Masuk Bagian Humas

Pada gambar diatas menjelaskan bahwa gambar diatas merupakan tampilan pada surat masuk bagian humas. Pada bagian humas tidak dapat melakukan penambahan data surat masuk, pengeditan surat masuk yang telah diterima oleh bagian humas, dan penghapusan data surat masuk yang diterima bagian humas. Bagian Humas hanya bisa melakukan sedikit fungsi yaitu memprint disposisi surat dan pembuatan disposisi. Sehingga data surat yang diterima oleh humas lebih terkodinir.

\subsection{Tampilan Data Surat Keluar Bagian Umum}

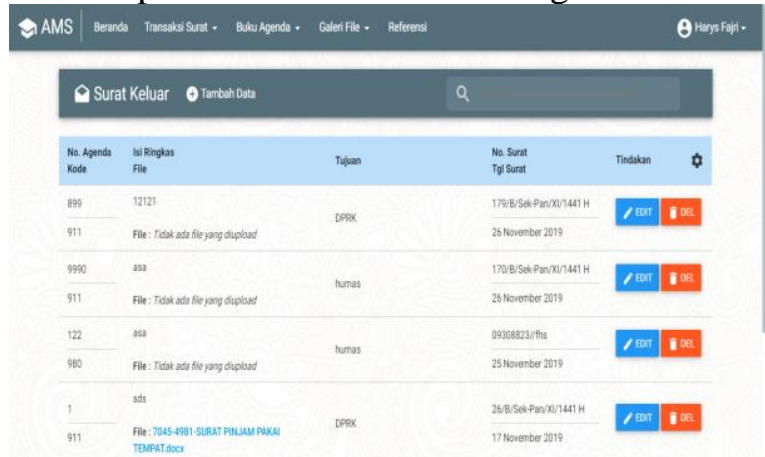

Gambar 10 Tampilan Data Surat Keluar Bagian Umum

Pada gambar diatas dapat dilihat tombol tambah data yang berfungsi untuk menambah data surat keluar yang akan dilakukan dari bagian umum. Dan pada bagian umum dapat melakukan beberapa tindakan seperti mengedit surat keluar dan menghapus surat keluar tersebut.

\subsection{Tampilan Data Surat Keluar Bagian Humas}

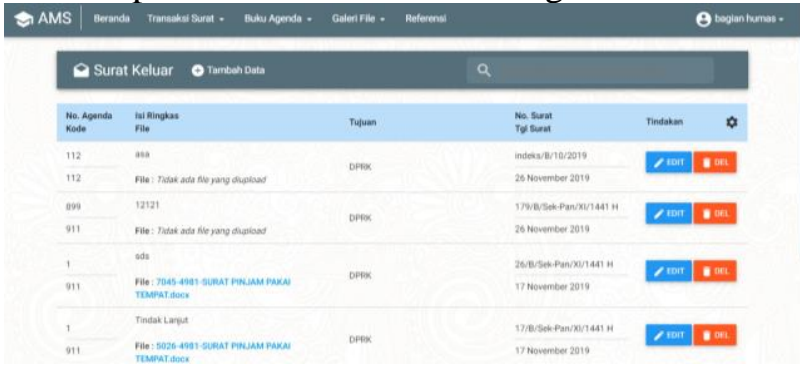

Gambar 11 Tampilan Data Surat Keluar Bagian Humas

Pada gambar diatas dapat dilihat tombol tambah data yang berfungsi untuk menambah data surat keluar yang akan dilakukan dari bagian humas. Dan pada bagian umum dapat melakukan beberapa tindakan seperti edit dan delete. Pada 
bagian ini hanya menampilkan surat keluar yang di keluarkan oleh humas.

\subsection{Tampilan Buku Agenda Surat Masuk}

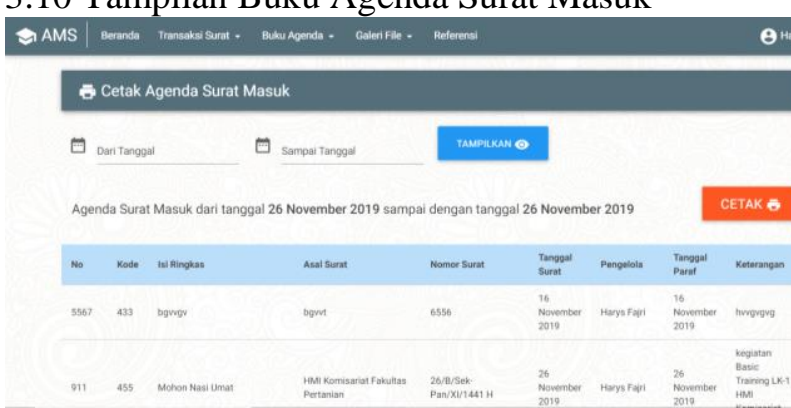

Gambar 12 Tampilan Buku Agenda Surat Masuk

Pada gambar 12 merupakan gambar buku agenda surat masuk yang memiliki fungsi untuk melakukan pencetakan seluruh data surat masuk mulai dari waktu yang di tentukan hingga ke waktu yang ditentukan berikutnya, sehingga pencetakan data seluruh surat masuk sebagai data manual book yang berguna untuk sebagai berkas hard copy.

\subsection{Tampilan Buku Agenda Surat Keluar}

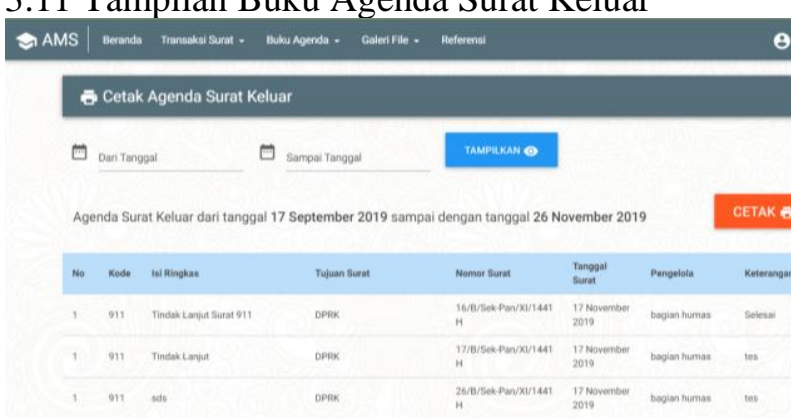

Gambar 13 Tampilan Buku Agenda Surat Keluar

Pada gambar 14 merupakan gambar buku agenda surat keluar yang memiliki fungsi untuk melakukan pencetakan seluruh data surat keluar mulai dari waktu yang di tentukan hingga ke waktu yang ditentukan berikutnya, sehingga pencetakan data seluruh surat keluar sebagai data manual book yang berguna untuk sebagai berkas hard copy.

\subsection{Tampilan Galeri File Surat Masuk}

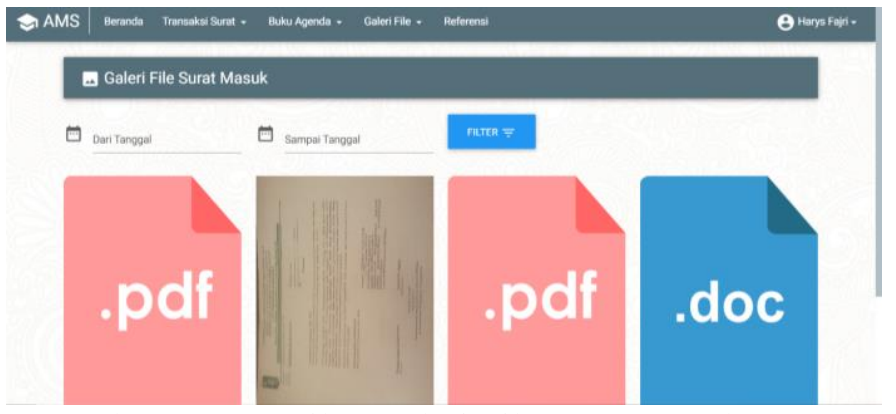

Gambar 14 Tampilan Galeri File Surat Masuk

Pada gambar diatas merupakan tampilan seluruh file-file yang di unggah pada surat masuk dengan ekstensi file berupa *.JPG, *.PNG, *.DOC, *.DOCX, *.PDF dengan ukuran maksimal file 2 MB. Pada bagian ini berfunsi untuk melihat ataupun mendownload kembali file-file yang telah diunggah sebelumnya, sehingga meningkatkan keamanan akan hilangnya data dan memudahkan pengguna untukk mencari file-file yang diperlukan.

\subsection{Tampilan Galeri File Surat Keluar}

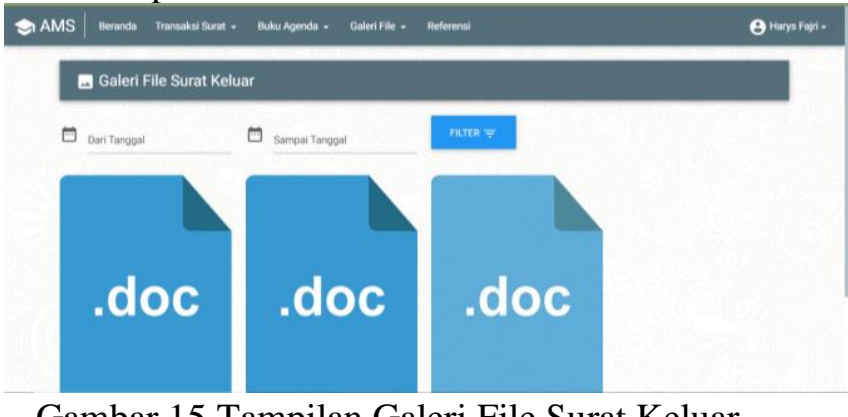

Gambar 15 Tampilan Galeri File Surat Keluar

Pada gambar diatas merupakan tampilan seluruh file-file yang diunggah pada surat keluar dengan ekstensi file berupa *.JPG, *.PNG, *.DOC, *.DOCX, *.PDF dengan ukuran maksimal file 2 MB. Pada bagian ini berfunsi untuk melihat ataupun mendownload kembali file-file yang telah diunggah sebelumnya, sehingga meningkatkan keamanan akan hilangnya data dan memudahkan pengguna untuk mencari file-file yang diperlukan. 


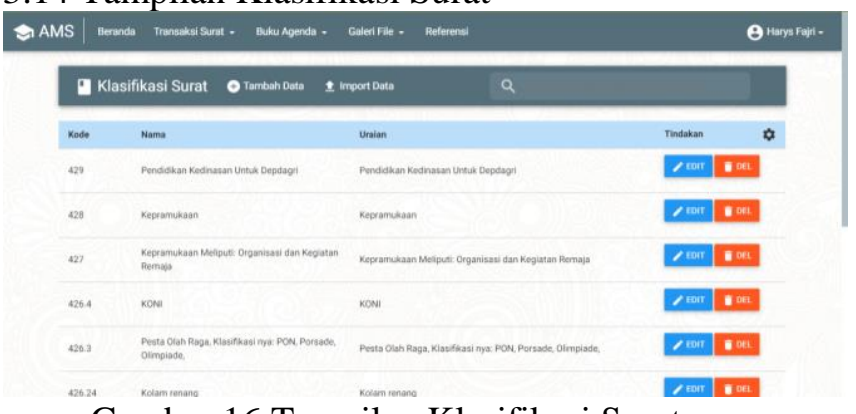

Gambar 16 Tampilan Klasifikasi Surat

Pada gambar diatas menjelaskan seluruh datadata referensi surat seperti kode surat, nama, uraian, dan tindakan pada klasifikasi surat. Kegunaan klasifikasi surat berguna sebagai referensi kode-kode surat yang berikutnya menjadi pedoman bagi pegawai.

\section{Kesimpulan}

1. Dengan adanya sistem ini kepala bagian atau pegawai kantor dapat mengirim dan menerima langsung surat, dengan cara login di komputer tanpa harus mendatangi kantor bagian satu persatu seperti sekarang ini

2. Sistem ini dapat menampilkan pemberitahuan atau notifikasi setiap adanya surat yang diterima oleh kantor setiap bagian yang melalui pendataan pada kantor bagian umum Setda Kota Langsa

3. Sistem ini dapat melihat seluruh surat yang diterima kantor, dibandingkan dengan sistem pendataan surat yang sebelumnya hanya melalui manual book

\section{Daftar Rujukan}

[1]Luqman, Muhammad. 2013. Pembangunan Sistem Informasi Manajemen Surat Masuk dan Surat Keluar Pada Bagian Umum Sekretariat Daerah Kabupaten Pacitan. Pacitan. Journal Speed.

[2] P., Dessyanto Boedi, dkk. 2008. Aplikasi SMS Notifikasi Kesehatan Balita. Yogyakarta. Jurusan Teknik Informatika UPN "Veteran".

[3]Rahardja, Untung, dkk. 2018. Pemanfaatan Automated Email System (AEMS) Sebagai Media Notifikasi Penilaian Hasil Belajar. Tangerang. STMIK Raharja.

[4]Sasongko, Jati dan Dwi Agus Diartono. 2009. Rancang Bangun Sistem Informasi Manajemen Surat. Semarang. Jurnal Teknologi Informasi DINAMIK Volume XIV, No.2, Juli 2009. 